Agriculture, Agribusiness and Biotechnology

\title{
Biofumigation Studies by Using Raphanus sativus and Eruca sativa as a Winter Cycle Crops to Control Root-knot Nematodes
}

\author{
Gökhan Aydınlı ${ }^{1 \mathrm{e}}$, Sevilhan Mennan ${ }^{1 *}$ \\ ${ }^{I}$ Ondokuz Mayis Universitesi - Plant protection Ondokuz Mayls Un., Agr. Fac. Samsun, Samsun Turkey; ${ }^{2}$ Ondokuz \\ Mayis Universitesi - Bafra Vocational School Samsun Turkey
}

\begin{abstract}
An experiment was conducted to search the efficacy of radish (Raphanus sativus) and arugula (Eruca sativa) for the control of Meloidogyne arenaria in the commercial tomato growing greenhouse. $R$. sativus and E. sativa were used as winter cycle crops and lettuce as a susceptible crop and 4 months after sowing, host level of the treatment plants was evaluated. All parts of $R$. sativus and E. sativa were incorporated except lettuce was covered with transparent polyethylene film for 4 weeks. $R$. sativus and E. sativa had not any root galls, and these plants caused reducing number of juveniles in the soil, in contrast to control and lettuce plots before growing tomato. Gall index and egg masses were significantly decreased on tomatoes in plots of applied biofumigation with E. sativa and $R$. sativus. It was concluded that growing $R$. sativus and E. sativa as a winter cycle plants before susceptible plants would be helpful to reduce the damage of root-knot nematode M. arenaria and increased crop yields.
\end{abstract}

Keywords: Meloidogyne arenaria, Raphanus sativus, Eruca sativa, biofumigation, crop yield.

*Author for correspondence: smennan@omu.edu.tr 


\section{INTRODUCTION}

The root-knot nematodes (Meloidogyne spp.) are the first in "top 10" list of plantparasitic nematodes according to scientific and economic importance ${ }^{1}$. The genus is close to 100 species and their host range is almost all plants in all over the world ${ }^{2}$. Control of root-knot nematodes is extremely difficult and environmentally compatible approaches have gained importance in recent years. Chemical fumigants which have been used at a field scale for many years to reduce nematodes had to be limited in their use over the last years, because of the toxicity to human and nature ${ }^{3}$. Therefore, an increasing interest in ecological approaches that do not have harmful effects on natural life and human health lead to the search for alternatives to fumigants that is highly included plants with natural compounds on the suppression of pests and pathogens. Today, biofumigation is the leader option for the application of fumigation by natural means. In numerous reports, biofumigation with Brassicaceae was found effective to control soil pests including root-knot nematodes ${ }^{4,5}$. Most Brassica species release chemical compounds that may be toxic to soil borne pathogens and pests, such as nematodes, fungi, and some weeds. Brassica species can provide greater than $80 \%$ soil coverage when used as a winter cover crop ${ }^{6}$. Because of their fast fall growth, brassicas are well suited to capture soil nitrogen $(\mathrm{N})$ remaining after crop harvest ${ }^{7}$.

Cultivars developed for high forage biomass or/and oilseed yield are also useful for the purposes of the cover crop. Raphanus sativus has potential for managing soilborne biotic factors such as Meloidogyne hapla when it can be used for multi-purpose attributes as the cash crop, trap crop, cover crop or biofumigant plant ${ }^{8,9}$. These are the main reason for the small- and large-scale cultivation of Brassicaceae. A trap crop allows host infection, but not development and/or completion of the life cycle of the pest ${ }^{10,11}$. As the green manure, $R$. sativus and other brassicas serve two purposes. Firstly, brassicas produce isothiocyanate as a by-product of glucosinolate break-down and often have a metham sodium like biofumigant action to suppress weeds, nematodes and other soil-borne pests and diseases ${ }^{3,8,9,12,13,14,15,16}$. Secondly, the nonvolatile plant residues recycle nutrients, enhance soil organic matter and improve soil quality, which are important factors towards gradually building ecologically sound management of biotic limiting factor(s) for healthy small- and large-scale production systems ${ }^{15,16}$. E. sativa acts both as a green manure and a nematode trap crop. The $E$. sativa attracts nematodes but they cannot reproduce on its roots, as a result, nematode populations reduce ${ }^{11,17}$. E. sativa has reported an effective trap crop for populations of M. hapla in sandy loam soil ${ }^{11}$.

The Black Sea Region of Turkey has been the leader in the production of Brassica species in winter season just only for the purpose of cash crops. Whereas, the growers have not been aware of the potential of biofumigation by using these species. Therefore, the aim of this study was to determine the biofumigation effects of $R$. sativus and E. sativa on the root-knot nematode and tomato yield for the first time for the greenhouse in this region. Additionally, experiments were conducted in naturally infested commercial greenhouses to show how to use the $R$. sativus and E. sativa for the purpose of biofumigation to growers that have complained the root-knot nematode problem for many years in summer cash crops.

\section{MATERIAL AND METHOS}

\section{Experimental area}

The experiments were conducted in two commercial greenhouses, located at Adaköy village of Bafra Plain in Samsun Province, (latitude 41 $35^{\prime} 46.3^{\prime \prime} \mathrm{N}$, longitude 
$\left.35^{\circ} 53^{\prime} 42.1^{\prime \prime} \mathrm{E}\right)$. The soil of greenhouses was characterized by sandy soil with heavily $M$. arenaria infested (approximately $20 \mathrm{~J} 2 \mathrm{~s}$ per 100 gram of soil) because of the previous nematode-susceptible eggplant and tomato crops. Identification of the rootknot nematode species was done by perineal patterns and esterase phenotypes of females obtained from roots of previous crops in the greenhouse (Fig. 1).

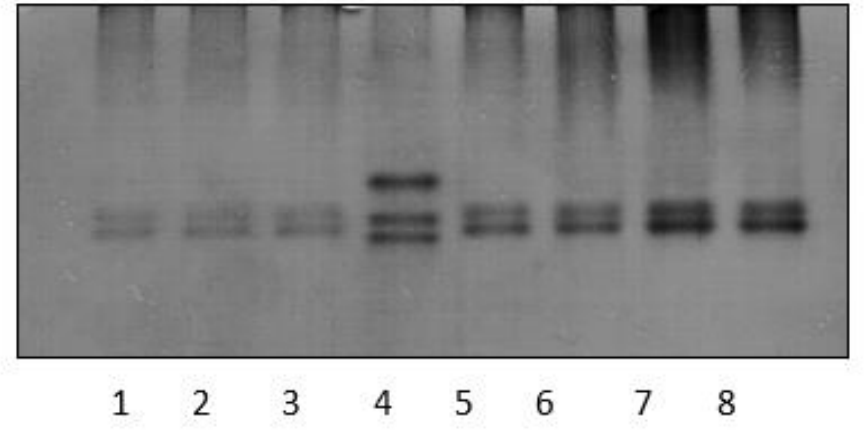

A

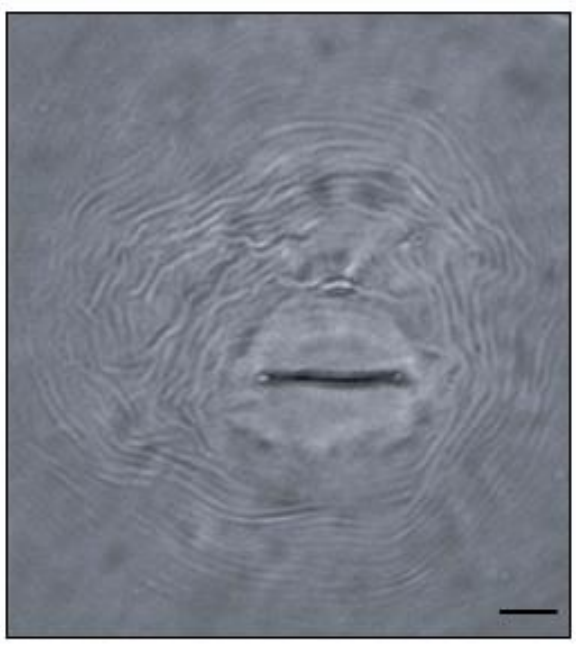

B

Figure 1- A. Species-specific esterase phenotypes of Meloidogyne arenaria on Polyacrylamide gel (7\% gradient). Lines 1-3, one egg-laying female; line 4, three egg-laying females with $M$. javanica as the reference; lines 5-6, three egg-laying females; lines 7-8, five egg-laying females. B. Perineal patterns of M. arenaria . Bars $=20 \mu \mathrm{m}$.

\section{Preparation of soil and greenhouses}

Greenhouses were plowed to $30 \mathrm{~cm}$ depth by the garden tiller. Sixteen individual plots were arranged $5 \times 2 \mathrm{~m}^{2}$ with the $1 \mathrm{~m}$ interval between cross plots (28 November 2009). E. sativa (cv. Istanbul) and white head $R$. sativus (cv. Semito) seeds were sterilized before using and sowed in an arranged plots as a recommend amount by the seed company (30 kg/ha) (05 December 2009). The experiments were in a completely randomized block design with four treatments (E. sativa, $R$. sativus, lettuce as the nematode-susceptible plant, and untreated fallow plots as a control) and four replications.

\section{Collection of soil samples and nematode extraction}

Soil samples were taken for each plot from presowing of Brassica species to postharvest of tomato plants for determination population densities of second-stage juvenile (J2) in the soil and from 28 November (presowing of winter plants) to 30 March (preincorporation). Soil samples were collected from each plot monthly to detect the effect of brassica plants on the $\mathrm{J} 2$ during the growing period. To detect initial and final populations of $\mathbf{J} 2$, soil samples were taken in post-incorporation (30 April) and in post-harvest of tomatoes (30 September), respectively. At each time of sampling, subsamples were taken from $30 \mathrm{~cm}$ depth of each plot using a digging shovel and samples for each plot consisted mixture of 10 subsamples were placed into separate polyethylene labeled bags, stored at $4{ }^{\circ} \mathrm{C}$ until processed. Second stage juveniles were extracted from 100-gram soil by tray method 18 and counted under the stereobinocular microscope. 


\section{Incorporation of Brassica plants and evaluation of their biofumigation effects on tomato}

Winter plants were grown for 4 months (from 5 December 2009 to 30 March 2010) and randomly selected 10 plants of each plot were rooted to obtain host suitability level. The roots were assessed using $0-5$ gall index $(0=$ no gall, $1=1-2,2=3-10$, $3=11-30,4=31-100,5>100$ galls per root system) ${ }^{19}$.

The winter brassica plants were incorporated into the top $25-30 \mathrm{~cm}$ of the soil by a garden tractor with a rotary tiller. The plots were irrigated to field capacity and covered with transparent polyethylene film (50-micron thickness) for 4 weeks. However, lettuce plants were harvested but not incorporated and plots of lettuce and untreated follow control were not covered. After removal of covered polyethylene film, all plots were prepared for tomato growing. For this purpose, beds were shaped and covered with black polyethylene mulching film after placing drip irrigation system. Nematode-susceptible tomato (Solanum lycopersicum) seedlings were transplanted in each plot at a distance of $50 \mathrm{~cm}$ in the row and $50 \mathrm{~cm}$ between rows. Tomato plants were grown by drip irrigation and fertilized in harmony with growers' practices. Five months after transplanting tomato seedlings, harvest was done and 15 tomato plants from each plot were randomly selected and fruit weight, stem height, and fresh stem weight were recorded. The roots of these plants were carefully removed and fresh root weights, gall, and egg mass index (0-5) per root system were determined. After removal of all plants from plots, soil samples were collected to determine the final populations of $\mathrm{J} 2$ and the reproduction factor $(\mathrm{Rf}=\mathrm{Pf} / \mathrm{Pi}$ where $\mathrm{Pi}=$ the initial population and $\mathrm{Pf}=$ the final population) were calculated ${ }^{20}$.

\section{Data analysis}

Data obtained from two separate greenhouses were pooled because of no significant differences according to ANOVA. Number of $\mathrm{J} 2$ in soil were transformed by using $\log _{10}(X+1)$ before analysis. Mean values were separated by Tukey's HSD test using the SAS statistical program ${ }^{21}$.

\section{RESULTS AND DISCUSSION}

Eruca. sativa and $R$. sativus, planted in the winter cycle as biofumigation crops, had no gall of their roots but root galls (2.1 of gall index) were present only nematodesusceptible lettuce plants as expected. Population number of J2s in the plots except that of control was gradually decreased from presowing of winter plants to February but increases in the number of $\mathrm{J} 2$ continued from February to pre-incorporation (March) (Fig. 2). After incorporation of brassica plants, J2s in soil decreased in plots where were shedding E. sativa. The plots which were grown lettuce showed the highest increase in the number of $\mathrm{J} 2$ soil. Before transplanting the seedlings of tomato, $\mathrm{J} 2 \mathrm{~s}$ in 100 gram of soil were 42, 18.5, 12, 5 and 10 in plots in which lettuce, untreated fallow, E. sativa and $R$. sativus were applied, respectively. 


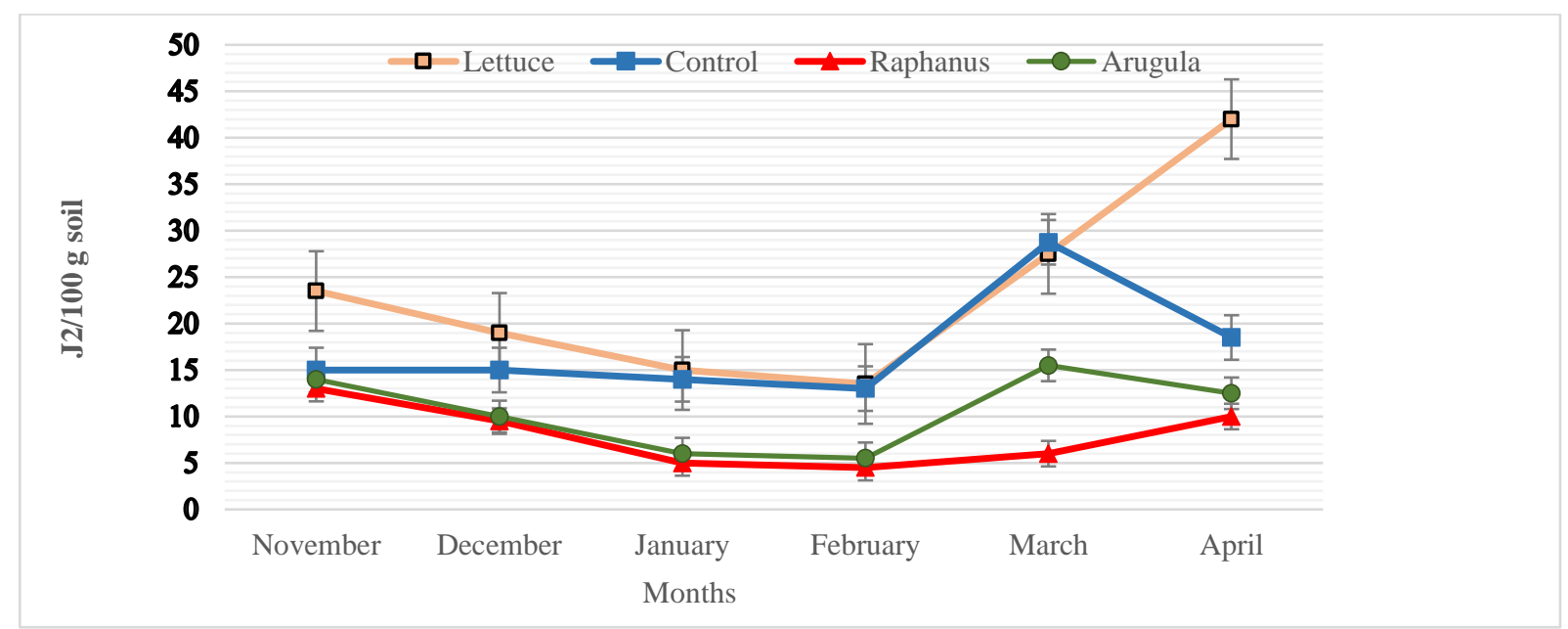

Figure 2. Change of second stage juveniles' populations of Meloidogyne arenaria in $100 \mathrm{~g}$ soil growing arugula (Eruca sativus), radish (Raphanus sativus), lettuce (Lactuca sativa) and control (fallow)

Experiments of nematode-susceptible tomato were terminated after 5 months because tomato plants in plots where only lettuce plants are grown were approaching to death. Moreover, tomato crops in plots treated with $R$. sativus and E. sativa were grown very well and continued to give fruit regularly. A significant reduction in the gall index of tomato roots was obtained from plots incorporated with brassica plants but not in plots treated with lettuce and fallow $(\mathrm{P} \leq 0.05)$ (Fig. 3). Gall indexes were detected 2.8 and 3.2 for roots of tomato in plots treated with E. sativa and $R$. sativus, respectively. Although values obtained from gall index of tomato roots in biofumigation plots were not significantly different each other, these values were significantly different from that of non-biofumigant plots which had more than 100 galls per plant $(\mathrm{P} \leq 0.05)$. However, the number of eggs indicating 3 in egg masses index of tomato roots obtained from plots treated with E. sativa was significantly less than plots treated with $R$. sativus $(\mathrm{P} \leq 0.05)$ (Fig 3). According to egg masses index, roots of tomatoes in plots with treated lettuce and fallow did not significantly differ from each other but differ from plots treated with brassica plants $(\mathrm{P} \leq 0.05)$. Reproduction factor based on J2s in soil at post-harvest of tomatoes was the only one character in data obtained from this study that was significantly different for all treatments $(\mathrm{P} \leq 0.05)$ (Fig. 3). The highest reproduction factor (1.78) was found in plots treated with lettuce followed by plots treated with fallow (1.23), R. sativus (1.12) and E. sativa (0.89). 


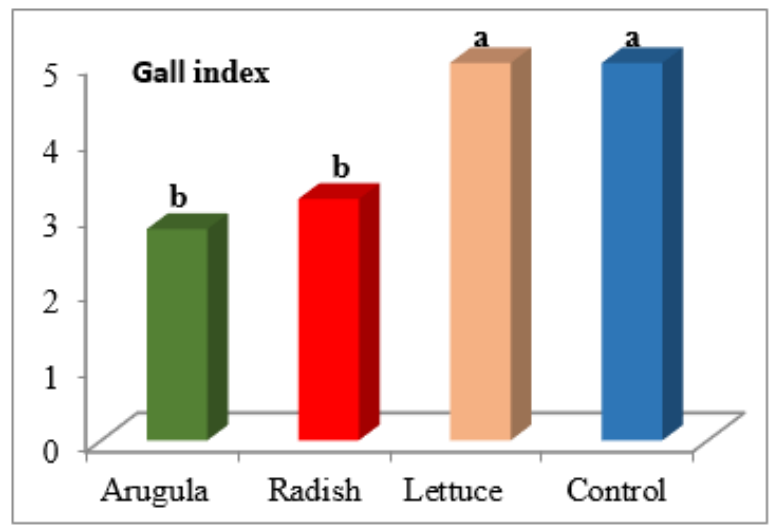

A

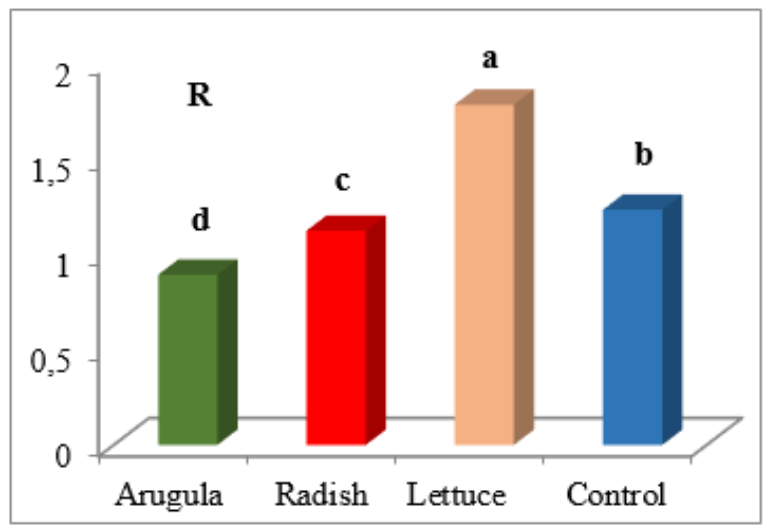

C

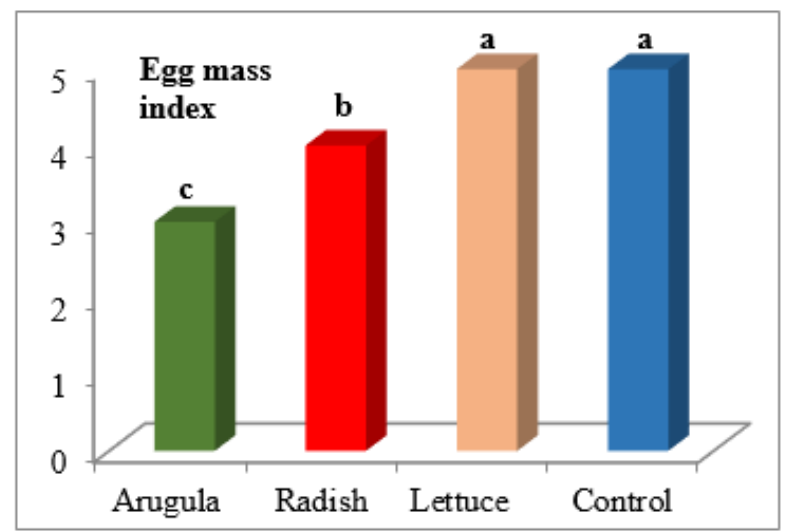

B

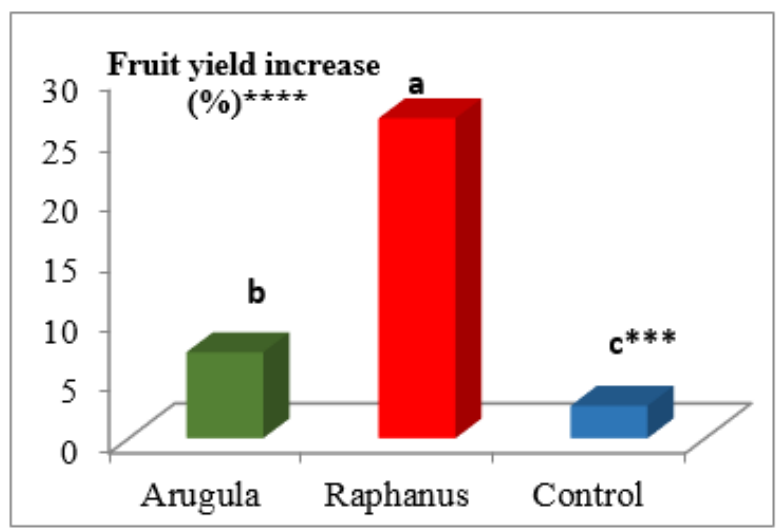

Figure 3.The (A) root gall index* and (B) egg mass index* (C) reproduction factor (Rf)** (D) fruit yield increase of tomato plants (Solanum lycopersicum) in the field which is naturally infested with Meloidogyne arenaria, planted after arugula (Eruca sativus), radish (Raphanus sativus) and lettuce (Lactuca sativa) in M. arenaria infested field.

* Scale used for gall and egg mass indices: 0-5 scale; where $0=$ no gall/eggs, $1=1-25,2=26-50,3=51-75,4=75$ 100 and $5=>100$ galls $/$ egg masses per plant. $* * \mathrm{R}_{\mathrm{f}}=\mathrm{Pf} / \mathrm{Pi}$; where $\mathrm{Pi}=$ the initial population and $\mathrm{Pf}=$ the final population. Means by the same letter are not significantly different according to Duncan's multiple range test at $\mathrm{P}=$ $0.05 * * * *$ Fruit increase was compared with lettuce and given percentage $(\%)$ of increase according to lettuce

Percentage of fruit yield increases was calculated based on tomato plants following lettuce because the lowest fruit weight in plots at post-harvest of tomatoes was detected in these plots. The most positive effect on fruit yield with $26.45 \%$ was observed in plots treated with $R$. sativus that was significantly differ from plots treated with both $E$. sativa and fallow $(\mathrm{P} \leq 0.05)$ (Fig. 3). Even fruit yields obtained from the plots treated with $E$. sativa was higher than that of fallow but not significantly. In terms of root weight, there was no difference between the treatments even including control (Data not shown).

In tomatoes grown after $R$. sativus and E. sativa, the host suitability levels were lower than that of the lettuce, nematode damage was reduced. As a result of mixing the plant parts of $R$. sativus and E. sativa into the soil, the populations of root nematode in the soil have decreased due to the secondary metabolites they have in their parts. This effect is also evident in the $\mathrm{J} 2$ population in the soil. The most important factor in this effect is glycosinolates. After Blau et al. ${ }^{22}$ discovered the first effects of herbivores on glycosinolates, much research has been done on this subject. Although almost all Brassicaceous have glycosinolates, several are good hosts for root-knot nematodes ${ }^{23}$, 
${ }^{24}$ but the results are different from each other; the least suitable hosts were wild rocket (Eruca vesicaria) for $M$. arenaria, $R$. sativus for $M$. incognita according to Liebanas and Castillo ${ }^{25}$. Eruca sativa and $R$. sativus were found as poor non-host species to the root-knot nematode ${ }^{26}$. Pattison et al. ${ }^{24}$ also found that $R$. sativus (oil radish) and Sinapis alba (white mustard) are consistently resistant to nematode reproduction and the formation of root galls. Most $R$. sativus cultivars (R.. sativus $\mathrm{ssp}$. oleiferus) were poor hosts to $M$. arenaria and $M$. javanica. The $E$. sativa cv Nemat was a poor host for $M$. hapla, M. incognita, M. javanica ${ }^{26}$. These results are in agreement with findings by Curto et al. ${ }^{10}$ who also reported that $B$. juncea cultivars were among the better hosts for $M$. incognita, and that $R$. sativus cv. Boss and $E$. sativa cv. Nemat were poor or nonhost. Inconstancy is mainly due to the amount of glycosinolate contained in the plants and their variability in the variety and environmental effects ${ }^{25}$.

One of the plants known to have a high amount of glycosinolate is $R$. sativus that combined relatively high levels of resistance with good biofumigant activity ${ }^{24}$. Many brassica plants, including E. sativa, possess biofumigant and trap crop qualities, and thus have been gaining popularity as potential alternatives to chemical fumigants. As part of a project to develop alternative control method for root-knot nematodes, this study was conducted to determine the effects of E. sativa and $R$. sativus. Recently, several studies have been carried out on the effect in the control of nematodes of green manure of Brassicaceae plants ${ }^{4,10,17,27}$. Lopez-Perez et al. ${ }^{28}$ showed that that wintergrown broccoli, followed by incorporating the crop residue into the soil, benefited a following $M$. incognita-susceptible vegetable crop. Black Sea Region is well known its Brassica production. So, biofumigation which is using Brassica plants is very suitable for this region. It needs to be more search, show and confirm the results thus farmers will be willing to produce Brassica plants before or together with the susceptible plants.

\section{CONCLUSIONS}

The working hypothesis that $R$. sativus and E. sativa as winter cycle crop will adversely affect populations of $M$. arenaria appears to be true. The study shows that $R$. sativus and E. sativa inhibit $M$ arenaria development and reproduction, hence its potential use as a trap crop for this important pest of vegetable and nursery crops. Using E. sativa cultivar, Curto et al. ${ }^{10}$ showed similar effects on the development and lack of egg mass production in $M$. incognita, a warm climate species. Whether $E$. sativa is to be used as a biofumigant when incorporated into the soil or as a trap crop depends on the prevailing field or agricultural problems. If used as a trap crop, its suitability as a host becomes important. Compared with lettuce, both E. sativa and $R$. sativus are the less suitable host for $M$. arenaria, which is a similar observation to those on $M$. incognita ${ }^{10}$ and $M$. hapla ${ }^{8}$. It is possible that being a less suitable host to root-knot nematodes than tomato may lead this cultivar of $E$. sativa and $R$. sativus to be categorized as a resistant crop or a less efficient trap crop. However, E. sativa's ability to allow nematode infection but limit development and egg production of rootknot nematodes should get careful consideration ${ }^{8}$. Also, Brassicas can provide greater than $80 \%$ soil coverage when used as a winter cover crop ${ }^{7}$. Because of their fast fall growth, brassicas are well suited to capture soil nitrogen $(\mathrm{N})$ remaining after crop harvest. The amount of nitrogen captured is mainly related to biomass accumulation and the amount of $\mathrm{N}$ available in the soil profile ${ }^{7,8}$. The use of Brassica green manures and seed meals provide promising alternatives to synthetic chemical fumigants that have an adverse effect on the environment and beneficial soil organisms, are toxic to humans. More research is needed to better determine site- and 
species-specific Brassica crop effects on pests ${ }^{29}$. Although comprehensive field studies are needed to test the cost-benefit analysis of E. sativa and $R$. sativus's trap crop potential, using $E$. sativa and $R$. sativus as a winter crop, would be helpful to have a less population level of root-knot nematodes in the soil.

\section{ACKNOWLEDGES}

We thank the growers (Turgay ÖZDEMIR) for allowing us to study their greenhouses that experiments conducted in Adaköy, Bafra, Samsun (No:69) and technical help for Tuba KATI.

\section{REFERENCES}

1. Jones J, Haegeman T, Danchin A, Gaur E G J, Helder H S, Jones J, et al. Top 10 plantparasitic nematodes in molecular plant pathology. Molecular Plant Pathology. 2013; 14: 946961.

2. Elling A A. Major emerging problems with minor Meloidogyne species. Phytopat. 2013; 103: 1092-1102.

3. Kirkegaard J A, Sarwar M. Biofumigation potential of brassicas. I. Variation in glucosinolate profiles of diverse field-grown brassicas. Plant Soil. 1998; 201:71-89.

4. Daneel M, Engelbrecht E, Fourie H, Ahuja P. The host status of Brassicaceae to Meloidogyne and their effects as cover and biofumigant crops on root-knot nematode populations associated with potato and tomato under South African field conditions. Crop prot. 2017; $1-9$.

5. Monfort W S, Csinos A S, Desaeger J, Seebold K, Webster T M, Diaz-Perez J C. Evaluating Brassica species as an alternative control measure for root-knot nematode ( $M$. incognita) in Georgia vegetable plasticulture. Crop Prot. 2007; 26: 1359-1368.

6. Trudgill D L, Blok V C. Apomictic, polyphagous root-knot nematodes: exceptionally successful and damaging biotrophic root pathogens. Annu. Rev. Phytopathol. 2001; 39:53-77.

7. Haramoto E R, Gallandt E R. Brassica cover cropping for weed management: A review. Renew Agr Food Syst. 2004; 19: 187-198.

8. Melakeberhan H, Mennan S, Ngouajio M, Dudek T. Effect of Meloidogyne hapla on oilseed $R$. sativus (Raphanus sativus) use. Nematology. 2008; 10: 375-370.

9. Halbrendt J M. Allelopathy in the management of plant-parasitic nematodes. J Nematol. 1996; 28:8-14.

10. Curto G, Dallavalle E, Lazzeri L. Life cycle duration of Meloidogyne incognita and host status of Brassicaceae and Capparaceae selected for glucosinolate content. Nematology. 2005; 7: 203-212.

11. Melakeberhan H, Xu A, Kravchenko A, Mennan S, Riga E. Potential use of E. sativa (Eruca sativa L.) as a trap crop for Meloidogyne hapla. Nematology. 2006; 8: 793-799.

12. McSorley R, Stansly P A, Noling J W, Obreza T A, Conner J M. Impact of organic soil amendments and fumigation on plant-parasitic nematodes in Southwest Florida vegetable fields. Nematropica. 1997; 27:181-189.

13. Hafez S L, Sundararaj P. Life cycle of duration of Meloidogyne incognita and host status of Brassicaceae and Capparaceae selected for glucosinolate content. Nematology. 2001; 7:203212.

14. Riga E, Collins H. Green manure effects on Meloidogyne chitwoodi and Paratrichodorus allius, economically important nematodes in the Pacific Northwest of the USA. Agroindustria. 2004; 3:321-322.

15. Ngouajio M, Mutch D R. Oilseed R. sativus: a new cover crop for Michigan. Michigan State Univ. Extension Bulletin E 2907, 2004. East Lansing.

16. Riga E, Mojtahedi H, Ingram R, McGuire A M. Green manure amendments and management of root-knot nematodes on potato in the Pacific Northwest of USA. In Nematology monographs and perspectives. Cook, R.C., Hunt, D.J. eds. 2004; 151-158.

17. Kruger D H M, Fourie J C, Malan A P. Cover crops with biofumigation properties for the suppression of plant-parasitic nematodes: a review. S Afr J Enol Vitic. 2013; 34:287-295. 
18. Hooper D.J. Extraction of free-living stages from soil. In Laboratory methods for work with plant and soil nematodes. Southey J F. eds.; Ministry of Agriculture, Fisheries and Food, London: Her Majesty's Stationery Office, London, UK, 1986; 5-30.

19. Taylor A L, Sasser J N. Biology, identification, and control of root-knot nematodes (Meloidogyne spp.). North Carolina State Univ. Raleigh Graphics, USA P. 1978; 111.

20. Sasser J N, Carter C C, Hartman K M. Standardization of Host Suitability Studies and Reporting of Resistance to Root-knot Nematodes. North Carolina State Graphics, Raleigh, NC, USA, 1984; 1-7.

21. Steel R G, Torrie J H. Principles and Procedures of Statistics. A Biometrical Approach. $2^{\text {nd }}$ ed., Mc grawhill co., Inc. 1980; USA.

22. Blau P A, Feeny P, Contardo L. Allyglucosinolate and herbivores caterpillars-contrast in toxicity and tolerance. Science. 1978; 4347: 1296-1298.

23. Sikora R A, Fernandez E. Nematode Parasites of Vegetables. In Plant Parasitic Nematodes in Subtropical and Tropical Agriculture. Luc M, Sikora R.A, Bridge J. eds.; 2nd Edition, CABI Wallingford, UK. 2005, 319-392.

24. Pattison A, Versteeg C, Akiew S, Kirkegaard J. Resistance of Brassicaceae plants to root-knot nematode (Meloidogyne spp.) in northern Australia. Int J Pest Manage. 2006; 52(1): 53-62.

25. Liebanas G, Castillo P. Host suitability of some crucifers for root-knot nematodes in southern Spain. Nematology. 2004; 6(1): 125-128.

26. Edwards S, Ploeg A. Evaluation of 31 Potential Biofumigant Brassicaceous Plants as Hosts for Three Meloiodogyne Species. J Nematol. 2014; 46(3):287-295.

27. Fourie H, Ahuja P, Lammers J, Daneel M. Brassicaceae-based management strategies as an alternative to combat nematode pests: a synopsis. Crop Prot. 2016; 80:21-41.

28. Lopez-Perez J A, Roubtsova T, Cara Garci M G, Ploeg A. The Potential of Five Wintergrown Crops to Reduce Root-knot Nematode Damage and Increase Yield of Tomato. $J$ Nematol. 2010; 42(2):120-127.

29. Stirling G R, Stirling A M. The potential of Brassica green manure crops for controlling root-knot nematode (Meloidogyne javanica) on horticultural crops in a subtropical environment. Aust J Exp Agr. 2003; 43, 623-630. 